\title{
The Sticky Cost on Greek Food, Beverages and Tobacco Limited Companies
}

\author{
Vasileios Kokotakis ${ }^{1}$, Georgios Mantalis ${ }^{2}$, Alexandros Garefalakis ${ }^{3}$, \\ Nikolaos Zanidakis ${ }^{4}$, George Galifianakis ${ }^{5}$
}

\begin{abstract}
:
The cost behavior is one of the most important aspect of the analysis of businesses profitability. The traditional model of study of its behavior requires strict proportion with the level of activity, something that is not shared by modern studies. To understand better the behavior of asymmetric cost, our work examines the behavior of the Greek retail food, beverages and tobacco companies. We studied 438 limited companies for a period of 12 years, and noticed that a 1\% increase in sales, leads to an increase of $1.011 \%$ of the cost, while the corresponding reduction lowers the cost of sales by 0,905\%. The industry addressed by our study, has a direct relation to all households. So, it is important the industry to be studied further, in order to give more opportunities and benefits for consumers and state. Last,, future studies can use our study in an attempt to understand better the behavior of asymmetric costs.
\end{abstract}

Key Words: Asymmetric Costs, Profit Forecast, Analysts Behavior, Corporate Governance JEL Classification:

${ }^{1}$ Accounting Department, Technological Education Institute of Crete, kokotakisb@hotmail.com

${ }^{2}$ Accounting Department, Technological Education Institute of Crete, mantalis10@hotmail.com

${ }^{3}$ Department of Social Science, Hellenic Open University, garefalakis@teicrete.gr

${ }^{4}$ Accounting Department, Technological Education Institute of Crete, zanidnik@gmail.com

${ }^{5}$ Accounting Department, Technological Education Institute of Crete, galifianakis@staff.teicrete.gr 


\section{Introduction}

The traditional model distinguishes the total costs into fixed and variable. It also dictates that the total cost varies depending on the fluctuation in production or sales (Norren 1991; Garrison \& Noreen, 2002). In the early 90s, studies consistently cited that costs tend not to change symmetrical or proportionally with the changes of an activity. In fact, dictate that changes in costs, are not solely determined by changes in production volume or capacity (Banker \& Johnston, 1993), stressing that some costs do not change, even if the activity is reduced (Malcom, 1991).

Considering then, the traditional model obsolete, Noreen \& Soderstrom (1997) and Cooper \& Kaplan (1998), were among the first to bibliographically begin studying the sticky cost. Supporting the above mentioned view, Anderson Banker and Janakiraman (2003) had been studying 7629 companies for over 20 years and noted that sales, general and administrative costs increased more on average $0.55 \%$ per $1 \%$ increase in sales but decreased only $0.35 \%$ per $1 \%$ decrease in sales. Essentially, the sticky cost is the cost that increases more with increasing sales than decreases when sales fell in respectively.

The sticky cost may be increased, but cannot be reduced in a short time (Mak et al., 1994). Some believe, that is a result of the intervention of managers in production and of the engineering operation of cost (ABJ, 2003; Kajiwara et al, 2011: Banker et $a l, 2006^{6}$. Instead, Shannon et al. (2007), reject the notion that the sticky cost is due to the interference of managers and that there are costs that are arising mechanically. While Balakrishnan et al. (2010) believe that some events that arise from the mechanical structure of cost are responsible for the asymmetries. In cost elements such as the proportion of fixed and variable costs, economies of scale and the reduction rate of sales, affect the degree of stickiness.

Balakrishnan et al. (2004) confirmed the existence of sticky cost on physical therapy clinics in the United States, and Balakrishnan et al. (2008) observed that the costs that have to do with care and treatment of patients, are more inelastic (sticky) than the remaining costs. Subramaniam and Weidenmier (2003), while studying the behavior of costs in various business sectors, found that sales, general and administrative costs and the cost of sales in all business sectors, have asymmetric

\footnotetext{
${ }^{6}$ The Banker, Ciftci \& Mashruwala (2006), analyzed how optimism or pessimism of managers affect the allocation of resources.])
} 
cost behavior, ie sticky, only when the income changes are higher than $10 \%$. Specifically:

- Manufacturing companies have a high sticky cost. This is due to the high

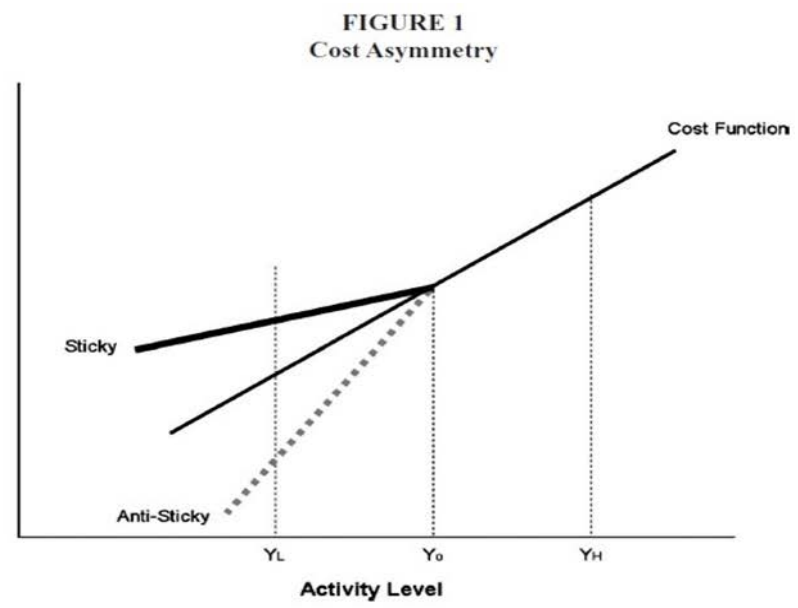

level of fixed assets.

- The traders have lower sticky cost. This is due to the existence of high competition, which makes businesses respond promptly to major changes.

- Finally, financial companies and the service companies observed some level of sticky cost which arises from the interest expenses (Financial), and workers in the census (for service providers).

Anderson et al, (2007), noted that while revenues are declining, the proportion of sales, general and administrative costs increased rather than decreased in proportion to sales, this may be due to the sticky cost. While Weiss (2010) argues that while there is the sticky cost there is also the anti-sticky cost, ie the cost that increases less when economic activity increases than decrease when economic activity is reduced by an equal amount.

In the above graph, the straight line represents the normal cost, the dashed one the anti-sticky, while the bold one represents sticky cost. Kama et al. (2010) believe that there are two possible sources of sticky cost. First, managers intentionally intervene in the production, to achieve personal goals and ambitions. Second, the limitation of technology. The study noted that companies with limited technology, exhibit high sticky cost. On the contrary, those with developed technology, exhibit sticky cost. It 
is also noted that adjustments of resources by managers to achieve personal goals, actually repel sticky cost and favor the symmetric cost.

Banker et. al. (2010) were based on the work of ABJ (2003) but disagreed with the assumption that the sticky cost occurs only when sales decline and concluded that the decisions of managers affect the cost, both to increase sales and reduce their Calleja et al (2006) studying businesses USA, UK, Germany and France, tried to see whether the system of corporate governance of the administrations has any impact on cost stickiness. So they noticed, that in the United Kingdom and the United States, where the administration to the interests of shareholders, giving fewer benefits to employees, revenues are higher and this leads to less sticky cost. On the other hand, because of the above benefits offered by administrations of German and French firms to workers, their income is lower and firms exhibit high sticky cost.

Banker et al. (2006) studied characteristics such as the bargaining power of unions, the level of unemployment benefits, legislation, etc., on a sample of 12,666 firms from 19 OECD countries for the period from 1996 to 2005. The results show that these characteristics affect the sticky cost in all businesses. For example, the strong bargaining power of trade unions leads to severe sticky cost, while a high level of unemployment benefits leads to low sticky cost. This study shows that the sticky cost is not mechanically derived from the changes of activities in production volume, but it comes from and is influenced by many factors such as aggregates, the state of the economy of the country etc..

Chen et al (2008) in a study they carried out on a sample of 1500 firms found a positive correlation between the incentives of managers and the degree of cost stickiness. Essentially they confirmed the theory of ABJ (2003), however putting corporate governance as a means of retaining managers from overspending. Weiss (2010) in his research on a sample of 2,520 firms over a period of 20 years, showed that companies with high sticky cost have less accurate earnings forecasts by analysts, than those with low sticky cost. This is because profits on companies with high sticky cost, are greatly reduced when economic activity is declining, while the cost remains constant. This leads to high volatility earnings complicating the work of analysts (Dichev\& Tang, 2008).

Banker et al (2012) agree with ABJ (2003) that the costs do not fluctuate with changes in sales, so there is asymmetry and note that when the sales of the previous 
period have increased we have sticky cost, and when the sales previous period have reduced we have anti-sticky cost. The need for information is very important for both investors and financial institutions. This is because, incorrect assessments of investors (Beyer et. al, 2010) and the limited financing of small firms (Felsesteinet. et, al., 1998), because of information asymmetry, lead to market failure. Bartik (1991) notes that the failure of the market is due to the fact that viable business plans are not supported by the private markets. Also the public sector should intervene to stimulate the market by offering low interest loans and to eliminate discrimination from asymmetries in information.

The analyst forecasts for earnings differ from the actual values (Womack (1996); Kothari (2001); Brown (2003). A major factor affecting the accuracy of the estimates, is the size of the brokerage companies where analysts are working, which is negatively correlated with the forecast errors (Thalassinos and Pociovalisteanu 2007, Mouna et al, 2010). The reason for this, is that large financial institutions provide access to a large database on macro-economical aggregates (Jennings, 1987), the right tools and attractive rewards for analysts (Mouna et al, 2010) .Bhushan (1989) correlated positively the size of the brokerage firms with the predictive accuracy of analysts.

The accuracy of the prediction is negatively correlated with the number of firms that analysts are tracking, which is attributed to the difficulty of analysts to deal with several companies simultaneously (Clement, 1999). On the contrary, Jacob et al (1999) argue that the number of firms tracked by analysts, does not affect the quality of their services. The time horizon, ie the difference between the forecast date and the earnings announcement date, is also an important factor in the prediction accuracy of earnings by analysts. Clement (1999) believes that prediction errors increase as the forecast horizon is prolonged.

Last but not least, Mouna et al. (2010) estimate that experience does not play a significant role in the ability of forecasting either, because skilled analysts have developed good relations with managers and form their forecasts according to their preferences, or because the configuration estimates vary from year to year, so even the most experienced analysts find it difficult to make a successful assessment. 


\section{Methodology}

Our methodology was based on the work of Baumgartenet. et.al. (2011). The ground work uses the model of ABJ (2003) which is calculated three times. In the first calculation the actual changes in the cost of sales are taken into account, in the second estimates of the changes with a long time horizon and in the third estimates of the changes with a short horizon.

In our research we used only the first regression model, since we wanted to study exclusively whether the sticky cost exists or not. The model has the following form:

$\log \left[\frac{\text { Cost }_{\mathrm{i}^{\prime} \mathrm{t}}}{\operatorname{Cost}_{\mathrm{i}^{\prime} \mathrm{t}-1}}\right]=\beta_{0}+\beta_{1} *\left[\frac{\text { Sales }_{\mathrm{i}^{\prime} \mathrm{t}}}{\text { Sales }_{\mathrm{i}^{\prime} \mathrm{t}-1}}\right] *$ Decrease $_{\text {Dummy }_{\mathrm{i}^{\prime} \mathrm{t}}} * \log \left[\frac{\text { Sales }_{\mathrm{i}^{\prime} \mathrm{t}}}{\text { Sales }_{\mathrm{i}^{\prime} \mathrm{t}-1}}\right]+\varepsilon_{i^{\prime} t}$

Where:

Cost $_{\mathrm{i}^{\prime} \mathrm{t}}=$ Sales $_{\mathrm{i} / \mathrm{t}}-$ Earnings $_{\mathrm{i} / \mathrm{t}}$.

$$
\begin{aligned}
& \text { Decrease }_{\text {Dummy }_{\mathrm{i}^{\prime} \mathrm{t}}}=1 \text { when Sales }_{\mathrm{i}^{\prime} \mathrm{t}}<\text { Sales }_{\mathrm{i}^{\prime} \mathrm{t}-1} \\
& \text { Decrease }_{\text {Dummy }_{\mathrm{i}^{\prime} \mathrm{t}}}=0 \text { when } \text { Sales }_{\mathrm{i}^{\prime} \mathrm{t}}>\text { Sales }_{\mathrm{i}^{\prime} \mathrm{t}-1}
\end{aligned}
$$

To calculate the above formula, we drew data of sales and profits from the financial statements of companies. The costs were calculated by deducting from sales profits. We also use a dummy variable (dummy variable), which takes the value:

- 0 when the sales of the current period increased compared with the previous

- 1 when the sales of the current period decrease from previous

The duration of the sample concerns 12 years, ie from 2001 to 2012 and the data are coming straight from the Hellas Stat SA (Greek Statistical \& Financial Information Company) and judged as reliable because Hellas Stat SA has the largest electronically editable database for economic and business information for more than 100,000 companies and 150 branches covering the entire spectrum of economic 
activity in Greece. In our sample, we chose (438) companies engaged in the retail sale of food, beverages and tobacco.

In our sample, we exclude business financial statements concerning economic years before 2001 or after 2012, this was because this time period was the greatest possible at Hellas Stat SA database, in order to have a large sample and emerge more reliable results .. Also, only SA companies were selected, excluding other types of companies such as (EПE. OE.EE). Finally, we excluded companies that include outliers on their balance sheets to reduce the error rate in the regression carried out. The table below presents descriptive statistics of our sample on the actual changes in sales and cost.

Table 1: Statistical description of sample

\begin{tabular}{|c|c|c|c|c|c|c|}
\hline & & Mean & $\begin{array}{c}\text { Standardd } \\
\text { Deviation }\end{array}$ & Q1 & Median & Q3 \\
\hline & $\frac{\text { Sales }_{\mathrm{i}^{\prime} \mathrm{t}}}{\text { Sales }_{\mathrm{i}^{\prime} \mathrm{t}-1}}$ & 1.086 & 0.33 & 0.93 & 1.01 & 1.13 \\
\hline Actuals & & & & & & \\
\hline & $\frac{\text { Cost }_{\mathrm{i}^{\prime} \mathrm{t}}}{\text { Cost }_{\mathrm{i}^{\prime} \mathrm{t}-1}}$ & 1.096 & 0.26 & 0.94 & 1.096 & 1.138 \\
\hline
\end{tabular}

\section{Results}

The following table shows the results for the regression of actual changes in costs for the upcoming changes in sales. The model explains $62.2 \%$ of the total variance. From the F-test (sig $<0.001$ ), we conclude that the model contributes significantly to our appreciation of the variables.

Table 2: Regression results

\begin{tabular}{|c|c|c|c|c|c|c|}
\hline $\begin{array}{c}\text { Coeff- } \\
\text { icient }\end{array}$ & & t-value & Sig & $\mathbf{R}$ & Adj* $^{2}$ & $\mathbf{N}$ \\
\hline$-0,002$ & $\beta_{0}$ & $-1,067$ & 0.286 & & & \\
\hline 1,011 & $\beta_{1}$ & 72,705 & 0.000 & 0.789 & $62,3 \%$ & 438 \\
\hline$-0,106$ & $\beta_{2}$ & $-5,006$ & 0.000 & & & \\
\hline
\end{tabular}


Our results are in agreement with those of Baumgartenet. al. (2011). The coefficient $\beta_{2}$ is negative -0.106 statistically different from zero at $1 \%$ ( $\mathrm{t}$ - statistic $\left.-5,006\right)$. Specifically in sales growth of $1 \%$ the cost increases $1011\left(\beta_{1}\right)$ and a decrease of $1 \%$ sales cost is the value of $0.905\left(\beta_{1}+\beta_{2}\right)$. The estimated value $\beta_{1}$ shows that total spending increased $1,011 \%$ for the sector food, beverages and tobacco in Greece per $1 \%$ increase in total sales. The combination of the values $\left(\beta_{1}+\beta_{2}\right)$ shows that the total cost decreased $0.905 \%$ per $1 \%$ decrease in sales.

\section{Conclusion}

Understanding the behavior of costs is fundamental to the management of each company. Managers are always interested in the cost of products and activities. In recent years, a new 'kind' of cost has emerged called "sticky cost", which increases more with increasing sales, than it will decrease when sales go down in the same proportion. This contrasts with the traditional costs (fixed and variable).

In the methodology, we are based on the theory of asymmetric behavior of costs mainly developed by Anderson Banker and Janakiraman (2003) and in particular on the application of Baumgartenet. al. (2011). Making regression on a sample of 438 firms regarding Food, Beverages and Tobacco sectors over 12 years (2001-2012) and we found that an increase in sales of $1 \%$ results in 1,011 increase of costs and that a decrease of $1 \%$ in sales results in 0.905 decrease in our costs . So, the costs are very inelastic $\left(\beta_{2}-0.106\right)$.

The results of the study have important implications for the professionals who evaluate changes in the costs in association with changes in revenue. Understanding sticky cost would help Greek companies to identify and manage more efficiently the capacity and resources.

Let us hope that future studies will try to further explain where sticky cost originates from. Accurate predictions are beneficial for businesses, in order for them to avoid unnecessary expenses and to make appropriate decisions in the right moments. To conclude, it is important for economic analysts to have good communication with managers so that they can conduct their work with greater accuracy. 


\section{References}

Anderson, M.C., Banker, R. and D. and Janakiraman, S. N. (2003), “Are selling, general, and administrative costs "sticky"?”, Journal of Accounting Research 41(1) pp. 47 - 63.

Anderson, M.C, Banker, R., Huang, R., and Janakiraman, S.N. (2007), “Cost Behavior and Fundamental Analysis of SG \& A Costs”, Journal of Accounting, Auditing and Finance 22 (1) pp 1-28.

Balakrishnan, R. and Gruca, T.S. (2008), “Cost Stickiness and Core Competency: A Note”, Contemporary Accounting Research 25 (4) pp. 993-1006.

Balakrishnan, R., Labro, E. and Soderstrom, N. (2010) "Cost Structure and Sticky Costs", Working paper.

Balakrishnan, R., Petersen, M.J. and Soderstrom, N.S. (2004), "Does capacity utilization affect the "stickiness" of cost?", Journal of Accounting, Auditing and Finance 19(3): pp. 283-99.

Banker, R., Ciftci, D.M. and Mashruwala, R. (2010), "Managerial Optimism and Cost Behavior”.

Banker, R.D., and Johnston, H.H. (1993), “An Empirical Study of Cost Drivers in the U.S. Airline Industry”, The Accounting Review 68 (3) pp. 576-601.

Banker, R.D., Byzalov, D., Ciftci, M. and Mashruwala, R. (2012), "The Moderating Effect of Prior Sales Changes on Asymmetric Cost Behavior”, Working paper, University of Philadelphia.

Banker, R.D., Ciftci, M. and Mashruwala, R. (2006), "The Effect of Prior-Period SalesChanges on Cost Behavior”, Working paper, Temple University, The University ofTexas at Dallas, and Washington University in St. Louis.

Bartik, T.J. (1991), “Who Benefits from State and Local Economic Deuelopment Policies?”, (Kalamazoo, MI: W. E. Institute for Employment Research).

Beyer, A., Cohen, D.L.A. and T.Z. and Walther, B.R. (2010), "The financial reporting environment: Review of the recent literature".

Bhushan, R. (1989), "Firm characteristics and analyst following”, Journal of Accounting and Economics 11: 255-274

Calleja, K., Steliaros, M. and Thomas, D.C. (2006), “A Note on Cost Stickiness: SomeInternational Comparisons”, Management Accounting Research 17 (2) pp. 127 140.

Chen, C.X., Lu, H. and Sougiannis, T. (2008), "Managerial empire building, corporate governance, and the asymmetric behavior of selling, general and administrative costs", Working paper.

Clement, M.B. (1999), “Analyst Forecast Accuracy: Do Ability, Resources, and Portfolio Complexity Matter?” Journal of Accounting and Economics 27 (3) pp. 285-303.

Cooper, R. and Kaplan, R. (1998), “The design of Cost Management Systems: Text, Cases, and Readings”, Upper Saddle River, NJ: Prentice-Hall. 
Felsestein, D., Fleischer, A., and Sidi, A. (1998), "Market failure and the estimation of subsidy size in a regional entrepreneurship programme".

Garrison, R. and Noreen, E. (2002), “Managerial Accounting”, 10th edition. New York, NY: McGraw- Hill/Irwin.

Jacob, J., Lys, T.Z. and Neale, M. (1999), ”Expertise in forecasting performance of security analysts”, Journal of Accounting Economics, 28 pp. 51-82.

Jennings, R. (1987), "Unsystematic Security Price Movements, Management Earnings Forecasts, and Revisions in Consensus Analyst Earnings Forecasts.”, Journal of Accounting Research 25 pp. 90-110.

Kajiwara, T. and Yasukata, K. (2011), "Are Sticky Costs the Result of Deliberate Decision of Managers?” Working paper, Kinki University and Kobe University.

Kama, I., and Weiss, D. (2010), “Do Managers’ Deliberate Decisions Induce StickyCosts?” Working paper, Tel Aviv University.

Kothari, S.P. (2001), “Capital Markets Research in Accounting”, Journal of Accounting and Economics 31 (1-3) pp. 105-231

Mak, Y.T. and Rousch, M. (1994), "Flexible Budgeting and Variance Analysis in an Activity - Based Cost Environment”, Accounting Horizons, Vol. 8, № 2, pp. 93-103.

Norren, E. (1991), "Conditions under which Activity-based Cost Systems Provide Relevant Costs.” Journal of Management Accounting Research 3, pp. 159-68.

Shannon, W. and William (2007), "Understanding cost management: What can we learn from the evidence on "sticky costs?" .

Subramaniam, C. and Weidenmier. M., L. (2003), “Additional Evidence on the Sticky Behavior of Costs".

Thalassinos, I.E. and Pociovalisteanu, D.M. (2007), “A Time Series Model for the Romanian Stock Market”, European Research Studies Journal, Vol. X, (3-4), pp. 57-72.

Womack, K.L., (1996), “Do Brokerage Analysts' Recommendations Have Investment Value?”, Journal of Finance 51, pp. 137-167. 